\title{
HUBUNGAN ANTARA KADAR GLUKOSA DARAH DENGAN TEKANAN DARAH MANUSIA DI RW 03 KELURAHAN KEBAYORAN LAMA JAKARTA SELATAN
}

\author{
Syafa'at Ariful Huda \\ Prodi Pendidikan Matematika STKIP Kusumanegara Jakarta \\ E-mail: syafaathuda@yahoo.com
}

\begin{abstract}
This study aims to determine whether or not there is a relationship between blood pressure with human blood glucose in Kebayoran Lama village. This study was Carried out to the residents of $R W 03$, the which consists of $9 R T$ in Kebayoran Lama South Village area. the simple random sample was taken (sample random sampling) by taking 30 votes from the citizens of RT 01 to RT 09. The method used is descriptive method qualitative correlation techniques. The independent variable $(X)$ is the blood pressure and the dependent variable $(Y)$ is the concentration of glucose in human blood. The data obtained were first Analyzed with normality test wearing Lilliefors test, then test the correlation coefficient and significance test of correlation coefficients. From the test results obtained normality for the independent variable correlation coefficient of variables $X$ and $Y$ are calculated by product moment correlation analysis, and obtained $r x y=0379$. Next, calculate the coefficient significance by $t$-student obtained that $=2,168(=2: 05)$ so the conclusion is that there is a relationship between blood pressure levels of glucose in human blood.
\end{abstract}

Kata Kunci: tekanan darah, kadar g lukosa darah

Banyak sekali orang yang menderita tekanan darah tinggi (hipertensi), tiga puluh lima juta orang Amerika menderita penyakit ini (Diehl, 1999: 81) dan diabetes (tubuh tidak dapat menangani glukosa dan menimbunnya dalam tubuh sampai tingkat yang membahayakan), diderita oleh 30 juta orang di dunia dan diperkirakan 16 juta lebih dari setengahnya ada di Amerika (Diehl, 1999: 64). dampak dari kedua penyakit tersebut adalah akan menimbulkan penyakit-penyakit baru yaitu resiko serangan stroke, serangan jantung koroner, fungsi ginjal terganggu, penyakit arteri, dan lain-lain (Semple, 1996: 14).

Biasanya kita terkejut bila mengetahui bahwa kita menderita tekanan darah tinggi. Meskipun keadaan ini sangat umum (satu di antara sepuluh orang dewasa dalam hidupnya menderita tekanan darah tinggi). Tekanan darah tinggi seringkali baru diketahui ketika dilakukan pemeriksaan rutin tekanan darah oleh dokter atau menjalani pemeriksaan medis dalam hubungan dengan pekerjaan atau asuransi (Semple, 1996: 1-2). Orang yang menderita tekanan darah tinggi, tiga kali lebih besar kemungkinannya terkena serangan jantung, lima kali lebih besar kemungkinannya menderita kegagalan fungsi jantung, dan delapan kali lebih besar kemungkinannya terkena serangan stroke dibandingkan dengan orang yang tekanan darahnya normal.

Hipertensi merupakan faktor penyebab yang terpenting pada1.500.000 kasus serangan jantung, 500.000 kasus stroke yang dilaporkan setiap tahunnya dan 150.000 di antaranya berakhir dengan kematian. Empat puluh persen di antara mereka 
yang sembuh memerlukan perawatan khusus sepanjang sisa hidupnya dan sepuluh persen harus dirawat secara permanen di rumah sakit. Kira-kira dua juta korban stroke di Amerika Serikat terganggu kemampuannya disebabkan kelumpuhan (salah satu akibat tekanan darah tinggi) (Diehl, 1999: 81).

Tekanan darah dapat turun sebagai akibat perdarahan atau serangan jantung dan turunnya tekanan darah yang mendadak dapat menyebabkan hilangnya kesadaran. Bertentangan dengan pendapat umum, hampir tidak ada kondisi tekanan darah rendah menahun yang sepadan dengan penyakit tekanan darah tinggi. Umumnya, semakin rendah tekanan darah, semakin rendah resiko kematian dini, terjadinya stroke, serangan jantung dan penyakit arteri lain. Pada beberapa orang, saraf yang secara otomatis mempertahankan tekanan saat berdiri, tidak berfungsi dengan benar sehingga timbul rasa pusing dan kemudian orang itu jatuh pingsan. Namun, hal ini jarang terjadi dan mudah dibedakan dari kondisi umum yang tidak berbahaya seperti pingsan biasa. Pingsan lebih sering terjadi pada orang muda dan cenderung disebabkan oleh berdiri terlalu lama di lingkungan yang panas atau oleh emosi dan rasa takut. Hal ini tidak besar pengaruhnya terhadap kesehatan di masa yang akan datang. Kecenderungan jatuh pingsan akan berkurang dengan bertambahnya usia, sehingga hilangnya kesadaran mendadak pada orang tua mungkin mempunyai sebab-sebab lain dan membutuhkan pemeriksaan lebih rinci (Semple, 1996: 24).

Seorang penderita diabetes ditemukan setiap 50 detik. Sekitar 12$20 \%$ penduduk dunia diperkirakan mengidap penyakit ini dan setiap 10 detik di dunia orang meninggal akibat komplikasi yang ditimbulkan (Soegondo, 2010). setiap tahunnya penyakit diabetes dan komplikasinya menyebabkan 300.000 kematian, hal ini membuat diabetes menjadi salah satu penyebab utama kematian di Amerika, Bahkan DM membunuh lebih banyak dibandingkan dengan HIV/AIDS (Soegondo, 2010).

Setiap tahunnya, tiga dari sepuluh penderita diabetes berakhir di rumah sakit. Delapan dari sepuluh penderita diabetes mengalami ganguan penglihatan; diabetes merupakan penyebab utama kebutaan baru. Sebanyak $30 \%$ penderita DM mengalami kebutaan akibat komplikasi retinopati dan $10 \%$ harus menjalani amputasi tungkai kaki. (Soegondo, 2010), melipatgandakan kemungkinan menderita penyakit jantung, stroke dan impotensi. Penderita diabetes delapan belas kali lebih banyak terserang kerusakan ginjal yang serius, dibandingkan yang bukan penderita diabetes; $25 \%$ pasien yang harus menjalani cuci darah adalah penderita diabetes (Diehl, 1999: 64-66).

Berdasarkan pemikiran tersebut di atas diteliti lebih lanjut hubungan kadar glukosa darah dengan tekanan darah manusia di RW 03 Kebayoran Lama Jakarta Selatan.

\section{Tekanan Darah}

Tekanan darah adalah gaya yang dilakukan oleh darah terhadap satuan luas dinding pembuluh darah (Wulangi: 237). dimana tekanan darah sistolik nilai normalnya adalah 120 $\mathrm{mmHg}$ yang merupakan tekanan maksimal selama mendorong darah. Nilai normal tekanan darah diastolik adalah $80 \mathrm{mmHg}$ yang merupakan tekanan darah minimal dan terjadi pada akhir diastolik. Perbedaan antara keduanya adalah tekanan nadi, yang tergantung pada : 1 . Curah jantung, 2. Tahanan perifer. Tekanan arteri ratarata adalah tekanan diastolik ditambah sepertiga tekanan nadi (tekanan diastolik dikurangi tekanan sistolik). 
Tekanan arteri diukur dan diperlihatkan dengan osilotonometer otomatis (Muhimin, 2004: 23).

Tekanan darah arterial adalah kekuatan tekanan darah ke dinding pembuluh darah yang menampungnya. Tekanan ini berubah - ubah pada setiap tahap siklus jantung. Selama sistol ventrikuler, pada saat ventrikuler kiri memaksa darah masuk aorta, tekanan naik sampai puncak, yang disebut tekanan sistolik. Selama diastol tekanan turun. Nilai terendah yang dicapai disebut tekanan diastolik.

Tekanan darah sistolik dihasilkan oleh otot jantung yang mendorong isi ventrikel masuk ke dalam arteri yang terganggu. Selama diastol arteri masih tetap mengembung karena tekanan periferi dari arteriolarteriol menghalangi semua darah mengalir kedalam jaringan. Demikianlah maka tekanan darah sebagian tergantung kepada kekuatan dan volume darah yang dipompa oleh jantung, dan sebagian lagi kepada kontraksi otot dalam dinding arteriol (Pearce, 2006: 141 ).

Tekanan darah merupakan faktor yang amat penting pada sistem sirkulasi. peningkatan atau penurunan tekanan darah rata-rata akan mempengaruhi homeostasis di dalam tubuh. Dan jika sirkulasi darah menjadi tidak memadai lagi, maka terjadilah gangguan pada sistem transpor oksigen, karbondioksida dan hasil-hasil metabolisme lainnya. Di lain pihak fungsi organ-organ tubuh akan mengalami gangguan seperti gangguan pada proses pembentukan air seni di dalam ginjal ataupun pembentukan cairan serebrospinalis dan lainnya. Sehingga mekanisme pengendalian tekanan darah penting dalam rangka memeliharanya sesuai dengan batasbatas normalnya, yang dapat mempertahankan sistem sirkulasi di dalam tubuh (Masud, 2007: 116 ).
Tekanan darah rata-rata atau sering disebut "mean arterial pressure" (MAP) adalah tekanan ratarata di seluruh sistem arteri pada siklus jantung. Takanan darah rata-rata (TDR) diperoleh dengan cara membagi tekanan nadi dengan angka tiga dan ditambahkan pada tekanan diastolik. Adapun rumus yang dapat dipergunakan: $\mathrm{TDR}=1 / 3(\mathrm{Ts}-\mathrm{Td})+$ Td. Jika diketahui tekanan sistolik (Ts) normal $120 \mathrm{mmHg}$ dan tekanan diastolik (Td) $80 \mathrm{mmHg}$, maka tekanan darah rata-rata (TDR) sama dengan 96 mmHg. Dan tekanan ini yang merupakan hasil perkalian 'cardiac out put' atau curah jantung dengan tahanan perifer. Nilai tekanan darah tersebut dapat berubah-ubah sesuai dengan faktor yang berpengaruh padanya seperti curah jantung, isi sekuncup, denyut jantung, tahanan perifer dan sebagainya pada keadaan berolahraga, usia lanjut, jenis kelamin, suku bangsa, iklim dan penyakit-penyakit jantung atau pembuluh darahnya (Masud, 2007: 112).

\section{Macam-Macam Tekanan Darah}

1. Tekanan Darah Rendah

Tekanan darah normal sekitar 120/80 mmHg. Ada yang dilahirkan dengan tekanan darah rendah bila sejak muda di bawah 120/80 mmHg (hypotension) (Nadesul, 2008: 181-182). Tekanan darah terlalu rendah (anjlok) sama buruknya dengan bila tensi terlalu tinggi. Selain sebagai akibat tensi yang terlalu tinggi, kasus stroke dan jantung koroner bias terpicu juga karena tekanan darah yang anjlok. Darah tak deras lagi mengalir ke otak dan pembuluh darah koroner (Nadesul, 2008: 185).

2. Tekanan Darah Tinggi (Hipertensi)

The sixth report of the joint national Committee on prevention, detection, Evaluation, and 
treatment of high blood pressure (1977) mendefinisikan hepertensi sebagai tekanan darah sistolik 140 $\mathrm{mmHg}$ atau lebih atau tekanan darah diastolik $90 \mathrm{mmHg}$ ata lebih atau sedang dalam pengobatan antihipertensi ( Susalit, et al. 2001: 453). Sedangkan oleh Joint National Committee on Detection, Evaluation and Treatment of High Blood Pressure (JIVC) hipertensi sebagai tekanan yang lebih tinggi dari 140/90 $\mathrm{mmHg}$ dapat diklasifikasikan sesuai derajat keparahannya, mempunyai rentang dari tekanan darah (TD) normal tinggi sampai hipertensi maligna (Ruhyanudin, 2007 : 138). Tiga di antara empat faktor utama pendukung hipertensi berhubungan dengan makanan (Diehl, 1999: 87).

Berdasarkan penyebabnya, hipertensi dibedakan menjadi 2 golongan yaitu hipertensi primer yang tidak diketahui penyebabnya atau idiopatik dan hipertensi sekunder yaitu hipertensi yang disebabkan oleh penyakit lain. (Susalit, et al. 2001: 453)

a. Hipertensi primer adalah hipertensi yang penyebabnya tidak diketahui. Terjadi pada sekitar $90 \%$ penderita hipertensi. Hipertensi primer kemungkinan disebabkan oleh beberapa perubahan pada jantung dan pembuluh darah kemungkinan bersama-sama menyebabkan meningkatnya tekanan darah (Ruhyanudin, 2007 : 142).

b. Hipertensi sekunder akan sembuh sendiri setelah penyakit yang mendasari munculnya hipertensi sudah diatasi ( Susalit, et al. 2001: 454). Menurut Ruhyanudin (2007 : 142) Hipertensi sekunder adalah jika penyebabnya diketahui. Pada sekitar 5-10\% penderita hipertensi, penyebabnya adalah penyakit ginjal. Pada sekitar 1-2 \%, penyebabnya adalah kelainan hormonal atau pemakaian obat tertentu misalnya (pil KB).

c. Menurut Nadesul (2008: 190191) Berbeda dengan hipertensi primer yang belum tahu apa penyebabnya sehingga tidak bisa sembuh bila tidak mengkonsumsi obat, hipertensi sekunder bisa sembuh dengan sendirinya. Pada kasus hipertensi sekunder, obat tak perlu dilanjutkan lagi dan tensi darah umumnya kembali normal setelah penyakit yang mendasarinya teratasi. Oleh karena itu, upaya penanganan hipertensi primer lebih mendapatkan prioritas. Banyak penelitian dilakukan terhadap hipertensi primer baik mengenai pathogenesis maupun tentang pengobatannya (Susalit, et al. 2001:454).

\section{Kadar Glukosa Darah}

Kadar gula darah normal 60$120 \mathrm{mg} / \mathrm{dl}$ (milligram per 100 milimeter) sedangkan ukuran idealnya adalah 80-109 $\mathrm{ml} / \mathrm{dl}$ pada waktu puasa sebelum test darah dan $110-159$ pada 2 jam setelah makan kadar kolesterol tidak boleh lebih dari $200 \mathrm{mg} / \mathrm{dl}$ dengan LDL kurang dari $130 \mathrm{mg} / \mathrm{dl}$, dan HDL diatas $45 \mathrm{mg} / \mathrm{dl}$ dan trigeliserida dibawah 200 mg/dl (Vitahealth, 2006).

Kadar gula puasa atau glukosa fasting, yaitu hasil pemeriksaan kadar gula darah dari darah yang diambil pertama kali saat masih puasa, harga normalnya 60-100 md/dl. Kadar gula darah setelah makan atau glukosa past prandial adalah kadar gula darah dari darah yang diambil 2 jam setelah makan, harga normalnya $80-120 \mathrm{mg} / \mathrm{dl}$. Kadar gula darah sewaktu adalah kadar gula darah saat kapan saja, harga 
normalnya 70-110 mg/dl (Djojodibroto, $2003: 58-59$ ).

Menurut Djojodibroto (2003 :

82) Kadar gula di dalam darah tidak boleh lebih tinggi dari $180 \mathrm{mg} / \mathrm{dl}$ dan jangan lebih rendah dari $60 \mathrm{mg} / \mathrm{dl}$. Untuk mengatur hal ini tubuh mempunyai mekanisme pengaturannya. Apabila mekanisme ini tidak berjalan dengan baik maka akan terjadi penyakit diabetes mellitus.

Mengetahui kadar gula dalam darah berarti terkait dengan darah, komposisi darah, dan pembuluh darah. Darah adalah jaringan tubuh yang berbeda dengan jaringan tubuh lain, berada dalam konsentrasi cair, beredar dalam suatu system tertutup yang dinamakan sebagai pembuluh darah dan menjalankan fungsi transfor berbagai bahan serta fungsi homeostasis (Sadikin, 2001 : 2). Volume darah secara keseluruhan kirakira merupakan satu per dua belas berat badan atau kira-kira 5 liter: sekitar 55\% adalah cairan, sedangkan $45 \%$ sisanya terdiri atas sel darah. di waktu sehat volume darah adalah konstan dan sampai batas tertentu diatur oleh tekanan osmotik dalam pembuluh darah dan dalam jaringan (Pearce, $2006: 133$ ). Menurut Poedjiadi (2006: 206) Darah terdapat dalam tubuh kira-kira 5 liter dan teridiri atas 3 liter plasma darah dan 2 liter cairan dalam sel darah, yaitu sel darah merah dan sel darah putih.

Komposisi darah, Menurut Ruhyanudin (2007 : 14) Darah merupakan media transportasi oksigen, karbondioksida, dan metabolit. Jadi darah merupakan pengatur keseimbangan asam basa, suhu, dan hormon. Darah berisi elemen-elemen yang mengangkut oksigen ke sel jaringan, phagositosishomeostatis dan fibrinolis. Dalam darah terdapat eritrosit, leukosit, dan trombosit, meskipun $55 \%$ elemen darah adalah plasma darah.
Susunan darah, serum darah atau Plasma terdiri atas:

Air $\quad: 91,0 \%$

Protein : 8, $0 \%$ (Albumin, globulin, protrombin, dan fibrinogen )

Mineral : $0,9 \%$ (Natrium Khlorida, Natrium Bikarbonat, garam dari kalsium, fosfor, Magnesium dan besi, dan seterusnya)

Sisanya diisi oleh sejumlah bahan organik, Yaitu: Glukosa, lemak, urea, asam urat, kreatinin, cholesterol dan asam amino. Plasma juga berisi : Gas; Oksigen dan karbon dioksida, Hormon-hormon, Enzim dan Antigen (Pearce, 2006 : 133 ).

Menurut Djojodibroto (2003 : 56 ) Eritrosit atau butir-butir darah merah. Jumlah normalnya antara 4.500.000-6.000.000/ $\mathrm{mm}^{3}$ untuk lakilaki sedangkan untuk perempuan 4.300.000-5.500.000/ $\mathrm{mm}^{3}$. Bila hasil pemeriksaan $\mathrm{Hb}$ dan eritrosit kurang dari harga normal disebut anemia. Kalau dilihat satu per satu warnanya kuning tua pucat, tetapi dalam jumlah besar kelihatan merah dan memberi warna pada darah (Pearce, 2006 : 133134 ). Strukturnya terdiri atas membran sel yang merupakan dinding sel, substansi seperti spons yang disebut stroma dan hemoglobin yang menempati ruang-ruang kosong dari stroma (Wulangi : 35).

Menurut Wulangi (80) Sel darah putih yang dikenal juga sebagai leukosit terdapat di dalam darah dan cairan limfe, tetapi sering juga terdapat di cairan jaringan. Sel darah putih tergolong granulosit dibuat di sumsum tulang, sedangkan limfosit dan monosit diuat di nodus limfatikus. leukosit atau butir-butir darah putih jumlah normalnya 5.000-10.000 butir/ $\mathrm{mm}^{3}$. Bila kurang, kemungkinan adanya demam tifoid atau bisa juga AIDS. Bila lebih dari harga normal kemungkinan menderita penyakit infeksi (Djojodibroto, 2003 : 57 ). Sel darah 
putih (leukosit) rupanya bening dan tak berwarna, bentuknya lebih besar dari sel darah merah, tetapi jumlahnya lebih kecil (Pearce, 2006 : 135 ).

Plasma darah adalah cairan berwarna kuning yang dalam reaksi bersifat sedikit alkali. Berperan untuk medium (perantara) untuk penyaluran makanan, mineral, lemak, glukosa, dan asam amino ke jaringan. Juga merupakan medium untuk mengangkat bahan buangan: urea, asam urat, dan sebagian karbon dioksida (Pearce, 2006 : 138 ). bobot jenis plasma darah kirakira 1,024-1,028 (Poedjiadi, 2006: 210).

Trombosit adalah sel kecil kirakira sepertiga ukuran sel darah merah. Terdapat 300.000 trombosit dalam setiap milimeter kubik darah. Peranannya penting untuk penggumpalan darah (Pearce, 2006 : 138 ) dalam hal (1) melepaskan substansi yang mengaktifkan kofaktor bagi tromboplastin dan mengubah tromboplastinogen menjadi tromboplastin; (2) mempengaruhi pengkerutan (retraksi) koagulum. Tromboplastin itu sendiri merupakan penghambat kerja heparin, karena itu disebut juga anti-heparin (Wulangi : 85 ).

Pembuluh darah mengalirkan darah yang dipompakan jantung ke dalam sel. Arteri bersifat elastis mengedarkan darah yang dipompakan dari ventrikel kiri. Dinding pembuluh darah terdiri atas 3 lapisan : 1).Tunika Intima merupakan lapisan yang paling dalam yang bersentuhan langsung dengan darah 2). Tunika media merupakan bagian tengah yang bersifat elastis 3). Tunika adventisia adalah lapisan terluar dinding pembuluh darah (Ruhyanudin, 2007 : 11-12 ).

Pembuluh darah

yang

kecukupan gizi akan tetap lentur jika tubuh rutin bergerak. Gerak badan, apapun bentuknya, akan menambah kontraksi otot-otot anggota gerak. Dinding pembuluh darah di otot anggota gerak. Dinding pembuluh darah di otot anggota gerak, yang meringankan kerja jantung dalam memompakan darah, sama berperan juga ikut berkontraksi selama otot-otot anggota gerak berketul-berkendang (Nadesul, 2008: 190). Kita jumpai beberapa jenis pembuluh darah, Arteri dan Arteriol, yang membawa darah keluar dari jantung, selalu membawa darah segar berisi oksigen, kecuali Arteri pulmoner yang membawa darah "kotor" yang memerlukan oksigenisasi.

Vena juga berdinding tiga seperti arteri, tetapi lapisan tengah berotot lebih tipis, lebih muda kempis, dan kurang elastis daripada arteri. Oleh karena darah dalam anggota gerak berjalan melawan gaya berat, maka vena mempunyai katup yang disusun sedemikian sehingga darah dapat mengalir ke jantung tanpa jatuh kembali ke arah sebaliknya. Katupnya berbentuk lipatan setengah bulan terbuat dari lapisan dalam vena yaitu endothelium, yang diperkuat sedikit oleh jaringan fibrus. Lipatan- lipatan itu saling berhadapan; pinggiran yang bebas menghadap ke arah darah mengalir. Bila vena mengembung karena penuh dengan darah maka vena itu jadi seolah-olah diikat pada beberapa tempat (Pearce, 2006 : 146 ).

Sistem peredaran darah (sistem kardiovaskuler) terdiri dari arteri, arteriola, kapiler, venula dan vena. 1). Arteri (kuat dan lentur) membawa darah dari jantung dan menanggung tekanan darah yang paling tinggi. Kelenturanya membantu mempertahankan tekanan darah di antara denyut jantung. Arteriola adalah pembuluh darah yang merupakan tempat utama tahanan terhadap aliran darah dan berperan dalam mendistribusikan atau membagi-bagi darah keberbagai alat tubuh (Wulangi : 
210). memiliki dinding berotot yang menyesuaikan diameternya untuk meningkatkan atau menurunkan aliran darah ke daerah tertentu. Kapiler merupakan pembuluh darah yang halus dan berdinding sangat tipis, yang berfungsi sebagai jembatan diantara arteri (membawa darah dari jantung) dan vena (membawa darah kembali ke jantung). Venula mengalirkan darah ke dalam vena kemudian kembali ke jantung. Vena memiliki dinding tipis, tetapi biasanya diameternya lebih besar daripada arteri, sehingga vena mengangkut darah dalam volume yang sama tetapi dengan kecepatan yang lebih rendah dan tidak terlalu di bawah tekanan (Ruhyanudin, 2007 : 12 ).

\section{METODE}

Penelitian ini dilakukan di RW 03 Kelurahan Kebayoran Lama Jakarta Selatan. Penelitian menggunakan metode survei dengan pendekatan korelasi product moment. Teknik pengumpulan data dilakukan melalui kuesioner yang telah disusun terlebih dahulu dan tindakan pengecekan kadar glukosa darah. Sampel yang diambil adalah 30 orang warga. Pengambilan sampel dilakukan dengan cara simple random sampling dengan cara mengundi. Pengumpulan data penelitian dilakukan melalui kuesioner, kemudian hasilnya dianalisis dengan menggunakan statistik deskriptif dan statistik inferensial.

\section{HASIL DAN PEMBAHASAN}

Hasil penelitian tekanan darah dengan kadar glukosa darah pada manusia, dari 30 orang responden yang diperiksa, didapat 10 orang $(33,33 \%)$ responden menderita tekanan darah tinggi dan 20 orang $(66,67 \%)$ responden lainnya tekanan darahnya normal. Sedangkan untuk kadar glukosa darah didapat 17 orang $(56,67 \%)$ responden menderita kadar glukosa diatas normal dan 13 orang $(43,33 \%)$ lainnya kadar glukosa normal.

Sedangkan dari usia yang kurang dari 50 tahun terdapat 9 orang (30\%), 2 orang $(6,67 \%)$ menderita tekanan darah tinggi dan 4 orang $(13,33 \%)$ menderita kadar glukosa di atas normal. Usia yang lebih dari 50 tahun terdapat 12 orang (40\%), 4 orang $(13,33 \%)$ menderita tekanan darah tinggi dan 7 orang $(23,33 \%)$ menderita kadar glukosa di atas normal. usia kurang dari 70 tahun terdapat 5 orang $(16,67 \%), 2$ orang $(6,67 \%)$ menderita tekanan darah tinggi dan 3 orang $(10 \%)$ menderita kadar glukosa di atas normal. dan untuk usia yang lebih dari 70 tahun terdapat 4 orang $(13,33 \%), 2$ orang $(6,67 \%)$ menderita tekanan darah tinggi dan 2 orang $(6,67 \%)$ menderita kadar glukosa di atas normal.

Dapat disimpulkan dari data yang diperoleh 20 orang $(66,67 \%)$ responden yang diperiksa yang lebih banyak cenderung terkena tekanan darah tinggi atau kadar glukosa di atas normal itu berusia 50 tahun lebih. Sedangkan untuk usia yang kurang dari 50 tahun lebih cenderung sedikit yang terkena tekanan darah tinggi dan kadar glukosa di atas normal yaitu hanya 6 orang $(20 \%)$ responden.

1. Tekanan Darah Sistol

Nilai tekanan darah sistol tertinggi sebesar $192 \mathrm{mmHg}$ dan nilai terendah $110 \mathrm{mmHg}$ dan nilai rata-rata 138,9

2. Data Tekanan Darah Diastol

Nilai tekanan darah diastol tertinggi sebesar $110 \mathrm{mmHg}$, nilai terendah $58 \mathrm{mmHg}$ dan nilai rata-rata 84,7.

3. Data Kadar Glukosa Dalam Darah Manusia

Nilai kadar glukosa dalam darah yang tertinggi sebesar $267 \mathrm{mg} / \mathrm{dl}$, nilai terendah $59 \mathrm{mg} / \mathrm{dl}$ dan nilai rata-ratanya 129,7 . 
Dari hasil perhitungan didapat $r_{x y}=0,21$ dan $r_{x y}=0,38$, karena $r_{x y}$ bernilai positif sehingga dapat disimpulkan tedapat hubungan yang positif antara tekanan darah sistol dengan kadar Glukosa dalam darah manusia. Kemudian $r_{x y}$ dikonsultasikan dengan tabel interpretasi koefisien korelasi nilai $r$ didapat bahwa tingkat hubungan kedua variabel adalah rendah

Dari hasil perhitungan didapat tingkat kontribusi kadar glukosa darah memberikan kontribusi sebesar 40,9\% terhadap tekanan darah manusia Maka regresi linier hasil tekanan darah (Y) kadar glukosa darah manusia $(\mathrm{X})$ adalah $\widehat{Y}=a+b X=70,133+0,110 X$

Berdasarkan hasil perhitungan koefisien kolerasi diperoleh koefisien korelasi antara tekanan darah dengan kadar glukosa dalam darah manusia 0,379. Hal ini menunjukkan bahwa kolerasi antara tekanan darah dengan kadar glukosa dalam darah berada pada interpretasi rendah. ( $t_{\text {hit }} 2,168$; sedangkan $t_{\text {tab }}$ 2,05) maka berarti $\mathrm{H}_{0}$ ditolak, Jadi terdapat hubungan antara tekanan darah dengan kadar glukosa dalam darah manusia.

\section{KESIMPULAN}

Berdasarkan hasil penelitian dapat disimpulkan bahwa terdapat hubungan antara tekanan darah dengan kadar glukosa dalam darah manusia. Besar hubungan antara tekanan darah dengan kadar glukosa dalam darah adalah 0,379 yaitu hubungannya dikategorikan rendah.

\section{SARAN}

1. Masyarakat diharapkan menjaga kesehatan, terutama tekanan darah, Sebab tekanan darah mempengaruhi kadar glukosa dalam darah manusia, dengan menjaga nilai normal tekanan darah, kita dapat mencegah timbulnya komplikasi penyakit yang disebabkan oleh tekanan darah tinggi. Khususnya dalam menjaga kesetabilan kadar glukosa dalam darah, karena membutuhkan kondisi tubuh dan pola makan yang sehat.

2. Guru diharapkan dalam pelaksanaan proses pembelajaran agar menyampaikan hasil penelitian ini pada sub pokok "Sistem Transportasi Pada Manusia", sehingga dapat mendorong siswa untuk meningkatkan wawasan keilmuan Biologi.

\section{DAFTAR PUSTAKA}

Diehl, Hans. 1999. Waspadai Diabetes, Kolesterol, dan Hipertensi. Terj. Budiati, Winarni. Bandung : Indonesia Publishing House.

Djojodibroto, Darmanto. 2003. Seluk Beluk Pemeriksaan Kesehatan. Jakarta : Pustaka Populer Obor.

Masud, Ibnu. 2007. Dasar - Dasar Fisiologi Kardiovaskuler. Jakarta : EGC.

Muhimin, Muhardi. Dahlan, Ruswan. Sunatrio, S dan Thaib Roesli 2004. Anestesiologi.Jakarta: Infomedika.

Nadesul, Handrawan. 2008. Sehat Itu Murah. Jakarta : PT Kompas Media Nusantara.

Pearce C. Evelyn. 2006. Anatomi dan Fisiologi untuk Paramedis.Terj. Handoyo, Yuliani Sri. Jakarta: Gramedia.

Poedjiadi, Anna. 2007. DasarDasar Biokimia. Jakarta : 
Universitas Indonesia UI-

Press.

Ruhyanudin, Faqih. 2007. Asuhan

Keperawatan Pada Klien

Dengan Gangguan Sistem

Kardiovaskular. Malang : Universitas Muhammadiyah Malang Press.

Sadikin, M. 2001. Biokimia darah. Wid ya Medika. Jakarta

Semple, Peter. 1996. Tekanan Darah Tinggi. Terj. Tjandrasa Meitasari Jakarta: Arcan.

Soegondo, S. 2010. Diabetes Mellitus. http://www. medicastore.com. Diakses 10 April 2010

Susalit, E. Kapojos .E.J. Lubis .H.R. 2001. Ilmu Penyakit Dalam Jilid II. Edisi ke-3. FKUI : Jakarta

Vitahealth. 2006. Asam Urat. Jakarta. PT Gramedia Pustaka Utama.

Wulangi S Kartolo. 1993. Prinsipprinsip Fisiologi Hewan. Jakarta: Proyek Pembinaan Tenaga Kependidikan Pendidikan Tinggi. 